\title{
KATSAUS SEURAN TOIMINTAAN TALOUDEN NÄKÖKULMASTA
}

euran kevät- ja syyskokouksien yhteydessä on ollut esillä seuran taloustilanne ja sen tuomat haasteet toiminnalle. Seurasta on viime aikoina eronnut erityisesti eläköitymisten myötä runsaasti pitkäaikaisia jäseniämme ja uusien jäsenten hankinta seuratoimintaan on tunnetusti nykyisin haasteellista. Olemme muiden Tsv:n jäsenseurojen suunnalta kuulleet samaa viestiä. Tässä yhteydessä haluamme kiittää pitkäaikaisia jäseniämme tuesta seuran kehittämiselle ja toiminnalle.

Jäsenmaksut talouden kivijalka Seuran toiminta nojaa vahvasti jäsenmaksutuottoihin. Toisin kuin esim. Suomen kirjastoseura, oma seuramme ei saa suoraa toimintatukea valtion varoista. Saamme Tsv:n kautta tukea ainoastaan kansainvälisten seurojen IFLA:n, LIBER:in ja UKSG:n jäsenmaksuihin. Seuran tilikauden tulos on muutaman vuonna ollut merkittävästi tappiolla. Tappioiden syinä ovat olleet sekä yksittäiset kertaluonteiset tapahtumat ja tilanteet, mutta myös maksamattomat jäsenmaksut, jotka rasittavat seuran taloutta merkittävästi. Seuran talous tuleekin saada tasapainoon mahdollisimman nopeasti. Huomionarvoista on, että suurin osa työelämän ulkopuolella olevan jäsenen jäsenmaksusta ja varsinaisen jäsenen jäsenmaksustakin yli puolet menee jäsenlehti Signumin kustannuksiin.

Korona-aika on vähentänyt seuran tuloja koulutustoiminnan osalta, mikä osaltaan vaikuttaa negatiivisesti talouskehitykseen. Samanaikaisesti kulut jatkavat kasvuaan. Tieteiden talo on menossa remonttiin kesällä $202 \mathrm{I}$ ja sen yhteydessä joudumme järjestämään mm. seuran postin vastaanoton uudelleen. Otamme seuran käyttöön maksullisen postilokero-osoitteen, koska uudistetuissa tiloissa ei enää jatketa nykyisen kaltaista postin vastaanottoa tuttuun Kirkkokadun osoitteeseen.

\section{Signumin tulevaisuudesta} kysely

Seurassa on jo ryhdytty toimenpiteisiin talouden tasapainottamiseksi 
mm. järjestelemällä seuran ja Karl Erik Henrikssonin rahaston kirjanpidot uudelleen seuran itse hoidettavaksi. Samalla on otettu käyttöön digitaalinen toimintaympäristö, mikä mahdollistaa jäsenten entistä paremman mahdollisuuden osallistua yhteiseen toimintaan paikkakunnasta riippumatta.

Hallituksen keskuudessa on keskusteltu vakavasti siitä, onko painetulla Signumilla vielä tulevaisuutta? Laadultaan korkeatasoisen ja ammattitaitoisesti toimitetun alamme julkaisun on katsottu olevan merkittävä jäsenetu, joka kolahtaa säännöllisin väliajoin jäsenten ja tilaajien postiluukusta. Signumin ulkoasu uudistettiin jokin aika sitten ja se on saanut jäsenistöltämme hyvää palautetta. Kuitenkin postimaksujen jatkuva kohoaminen rasittaa seuran budjettia lehden painatuskustannusten ohella. Painatuskustannusten kohoamista olemme pyrkineet hillitsemään pienentämällä Signumin painosmäärää.

Hallituksen piirissä onkin päätetty järjestää Signumin tulevaisuuden vaih- toehdoista jäsenkysely tänä keväänä. Kyselyssä kartoitetaan jäsenten toivetta jatkossa saada edelleen jäsenlehti painettuna tai sille mahdollisia vaihtoehtoja. Muistathan vastata kyselyyn!

\section{Uusia jäseniä seuran toimintaan}

Aktiivinen jäsentoiminta ja uudistuva jäsentyö korostuvat entisestään yhä nopeammin muuttuvassa toimintaympäristössä. Toivommekin jokaiselta jäseneltämme aktiivisuutta seuran toiminnan merkityksen esiintuomisessa sekä uusien jäsenten houkuttelemisessa ja kutsumisessa mukaan seuran toimintaan.

Myös uusien toimintaideoiden tuominen hallituksen tietoon on erityisen toivottavaa, joko olemalla yhteydessä suoraan hallituksen jäseniin, toimihenkilöihin tai tuomalla ne esiin seuran vuosikokousten yhteydessä. Seuran vahvuutena on aina ollut kyky uudistua - se tapahtuu jäsenistön eli meidän kaikkien toimeliaisuuden kautta.

\author{
Pälvi Kaiponen \\ puheenjohtaja
}

SinikKa LuOKKanen

varapuheenjohtaja

Suomen tieteellinen kirjastoseura 